\title{
Changes in Property Rights, Forest Use and Forest Dependency of Katu Communities in Nam Dong District, Thua Thien Hue Province, Vietnam
}

\author{
Tran Nam Thang ${ }^{1}$, Ganesh P. Shivakoti ${ }^{2}$, and Makoto Inoue ${ }^{3}$ \\ trannamthang@gmail.com, ganesh@ait.ac.th, mkinoue@fr.a.u-tokyo.ac.jp,
}

\begin{abstract}
Sustainable participatory management and conservation requires an understanding of site-specific, rights structure, resource use and resource dependency patterns over time. This paper documents these issues by examining the resource use pattern overtime by the Katu people in Nam Dong district, Thua Thien Hue province, central Vietnam, before and after allocation of natural forest to the households of the community. Household interview, key informant and group discussions were used for data collection and crosscheck. Descriptive analysis and pair-sample T-test are main tools used to explore those parameters. We found a weak performance of property rights and differences in the De facto to the De jure rights of forest recipients. On contrary to the increased rights, forest use and forest dependency of local people have been reduced due to the degradation of resources, and availability of alternative opportunities from emerging agriculture and animal grazing options. Considering dynamic nature of resource dependency overtime, it is necessary to consider in the post-allocation programme which embrace the local context to have better forest protection and management as well as the satisfaction of local people on the forest resources they manage.
\end{abstract}

Keywords:participatory management, forest allocation, property rights, Katu people, Vietnam

\section{INTRODUCTION}

There is a large body of research demonstrating that conservation of forests in situations where local people are dependent on the resource; requires some degree of 'people's participation.' Crafting the overall framework of participatory management and forest conservation for policy simulating at large scale, however, requires an understanding of the actual use and management and even the dependency on forest resources. Understanding the site-specific, property rights structure, forest use pattern and forest dependency is therefore fundamental in formulating co-management programmes that may be sustainable over the long-term. The in-depth attention on that property rights become crucial when property rights offer incentives for management; provide authorization and control over the resource; reinforce collective action; and assign rights to the users in demonstrating government commitment to devolution (Meinzen-Dick and Knox 2001). Therefore, property rights are a central issue of policy development that alters the governance structure and the rights of users over forest resources.

\footnotetext{
1 Faculty of Forestry, Hue University of Agriculture and Forestry, Thua Thien Hue province, Vietnam 2 Asian Institute of technology, P.O. Box 4, Klong Luang, Pathumthani 12120, Thailand 3 Graduate School of Agricultural and Life Sciences, The University of Tokyo, 1-1-1 Yayaoi, Bun kyoku, Tokyo 113-8657, Japan
} 
As a form of property rights, current policy in Vietnam has provisions for handover of natural forest to communities, similar to the community forestry programme of other Asian countries (The Vietnam Forestry Development Strategy for 2006 to 2020, issued by the Decision 18/2007/QD-TTg). This policy, initiated in 1995 through the pilots and experiments and latter is Law on Forest Protection and Development (2004), has dramatically changed the people-forest relationship and is the result of an evolution of policy that began in 1975 with the reunification of Vietnam. Through the programme, local people and communities are allocated forest and forest land for their own management.

Understanding property rights over a natural resource helps to identify incentives, disincentives, and ultimately the prospects for sustainable management and conservation of forests by communities. It is with this concern that in this paper, we evaluate forest-related property rights of rural, forest-accessing communities of the Katu, an important ethnic group in the remote regions of Thua thien Hue Province, central Vietnam. In addition, we also evaluate forest use and dependency of rural communities. Our focus is to examine how local people manage, use and protect forest resource allocated to them based on the changes in their property right toward forest resources, to what level they are dependent on their forest resources and are there any changes in their forest use and forest dependency since they are allocated.

In this paper, before we describe the major changes that have occurred in the rights systems of one important ethnic minority society of central Vietnam, the Katu and how they use and management of forest resources, we briefly trace the government policy over last three decades as they relate to the way people use and manage forest resources as a basis for investigating the changes in the property rights that have occurred in Katu society. We then review the existing literature on Property rights, forest devolution and CFM in Vietnam. From that, we describe the forest use and forest dependency that characterized Katu people's behavior before forest allocation and then describe the contemporary modalities of those community forest management parameters. Finally, we discuss the implications of those changes on the property rights, forest use and forest dependency for the future of community-based forest management in Hue in particular and overall governance of community forestry in general.

\section{THE POLICY CONTEXT}

In 1968, the Vietnamese government initiated a policy of resettlement and sedentarization. The sedentarization programme was applied to 'ethnic minorities' that lived in the mountainous regions of the country. Concurrently, a resettlement programme was implemented by moving the people of the ethnic majority Kinh into more remote regions because they were seen as a new frontier for national development. Labour, capital, and new technologies needed to be invested to release the immense productive potential of the uplands (Poffenberger et al. 1998).

In December 1986, Vietnam launched the 'Doi Moi,' a policy of economic renovation to promote economic growth and improve the people's livelihoods through the market economy with national enterprises as the leading sector. This ultimately led to the recognition that non-state forest enterprises could contribute to the management of forests.

In 1991, the Forestry Protection and Development Act was passed. This Act had three main features. First, it defined forest as land with existing forest, or as land designated for forest plantations. Second, it classified forests as Protection Forest (critical watersheds), 
Special Use Forest (including formally protected areas such as national parks) or Production Forest. Third, it specified that production forest could be allocated to state enterprises, households and corporations.

Decree 327/CT dated 19/11/1992 (for the period 1992 - 1998) aimed to re-green barren land in the country through an integrated rural development approach. However, in order to be implemented in reality, the national programme 327 was formed under the management and coordination of the two ministries: Ministry of Agriculture and Rural Development and Ministry of Finance in order to implement the Decree 327.

The Land Law of 1993 buttressed the Forest Protection and Development Act of 1991 by specifying that the land (such as production forest) should be formally allocated to the managing entity (household, a group of households, or an organization) for 50 years.

The government, in addition to the protection contracts as common means of involving local people in forest management, also issued a set of related polices to enforce forest protection. Logging bans (stipulated spatially since 1992), fines (Decree 77 in 1996), and expanded enforcement agencies (to make the chairman of the provincial people's Committee responsible for their managed forest in the Directive 286 in 1997) to increase state control over forest resources.

In 1994 the Government Decree 02/CP pursued allocation of forestland to various economic sectors for management and use for long-term and sustainable forestry development. In 1995, Government Decree 01/CP concentrated on forestland allocation for forestry purposes. In addition, the Decree 163/1999/ND-CP concerning of allocation and lease of forestry land to organizations, households and individuals for stable and long-term use for forestry purposes.

Since 1995, there were several pilots of Land use Planning and Land Allocation (LUPLA) implemented by GTZ-SFDP (German Technical Cooperation - Social Forestry Development Project) in Lai Chau \& Son La provinces in 1995; the allocation of forested land in Daklak province (1998). The pilot model was also implemented in Thua Thien Hue province (2000), Gia Lai province (2002), Quang Binh, Hoa Binh and DakNong provinces (2005)

In 2001, Decision 178/2001/QD-TTg concentrated on benefit sharing and responsibility of household and individual who got land and forest land through land allocation, rental or forest protection contracts.

The recent 2003 Land Law and the 2004 Forest Protection and Development law further defined local responsibilities and re-regulate the overall management of local authorities over forest resource. These laws gave legal rights to local people especially they recognized local communities as legal recipients of land use rights.

In 2006, the National Forestry Department launched the Community Forestry Management (CFM) pilot programme which embarks the establishment of CFM in 10 provinces, and they got the approval from Ministry of Agriculture and Rural Development (MARD) to apply the CFM in 40 pilot communes in the above mentioned programme.

TABLE 1 Major Policies regulating Community forestry in Viet Nam 


\begin{tabular}{|l|l|}
\hline 1991 & Law on Forest Protection and Development \\
\hline 1992 & Decree 327/CT aimed to re-green barren land in the country \\
\hline 1993 & Law on land use management \\
\hline 1994 & Decree 02/CP on allocation of forestland to various economic sectors \\
\hline 1995 & Decree No. 01/CP on contractual allocation of land for forestry purposes \\
\hline 1999 & $\begin{array}{l}\text { Decree 163/1999/ND-CP on allocation and lease of forestry land to organizations, } \\
\text { households and individuals for stable and long-term use for forestry purposes }\end{array}$ \\
\hline 2001 & $\begin{array}{l}\text { Decision 178/2001/QD-TTg on benefit sharing and responsibility of household and } \\
\text { individual who got land and forest land through land allocation, rental or forest } \\
\text { protection contracts. }\end{array}$ \\
\hline 2003 & Land Law \\
\hline 2004 & $\begin{array}{l}\text { Forest protection and } \\
\text { Management Law }\end{array}$ \\
\hline 2006 & $\begin{array}{l}\text { Decision 18/2007/QD-TTg: The laws gave rights to local people especially they } \\
\text { recognized local communities as legal recipients of land }\end{array}$ \\
\hline
\end{tabular}

In Thua Thien Hue province, the people's committee has the resolution 7c/NQ/HDND in1997 to implement the logging ban for the natural forest, increasing the planting to cover the barren hills, abandon lands. It also had the Decision 667/QĐ-UB in 2002 to form the working groups to implement the CFM, lease forest and forest land to households, individuals and communities following the Decree 163/1999/NĐ-CP. This is also thanks to the successful pilots in CFM in Thuy Yen Thuong village, Phu Loc district, Thua Thien Hue province initiated by the MARD through UNDP's Program for Forests (PROFOR) in 2000.

Through the development of the policy context, forestry in Vietnam has experienced changes from the nationalization of forest and then gradually decentralization from state to local management.

\section{PROPERTY RIGHTS, FOREST DEVOLUTION AND CFM IN VIETNAM}

Property is referred to things or assets (Bromley 1989b, Hann 1998, MacPherson 1978) while in the formal usage, it is referred as rights to things (Bromley 1989b, Bruce 1998, MacPherson 1978). Bruce (1998) stressed that the term "Property rights" is used to make clear the meaning of property. Schalager and Ostrom (1992) classified Property rights to resources into different types. The access right allows holders entering the forest and enjoying non-subtractive benefits. The withdrawal right allows them to obtain resource units of products from the forest. The Management is right to regulate internal use patterns and transform the forest by making improvements (e.g. thinning, planting, etc.). The Exclusion is right to determine who will have forest access and withdrawal rights, and how those rights are determined. The Alienation allows holdes to sell or lease above rights. These five fundamental rights are the main rule structures under which individuals formulate 'ownership', and therefore shape the relationships among people with the forest and amongst themselves. The property rights are de jure when resource users are granted officially the rights by the government and are given lawful recognition by formal, legal instrumentalities. Property rights can also be de facto when resource users cooperate to define and enforce rights among themselves. Within a single resource, de jure and de facto property rights can overlap, complement or even conflict with one another (Schlager and Ostrom 1992). 
Devolution is the transfer of authority over forest management decision-making from central government bureaucracies to local civil society actors, generally forest users and user organizations not created or controlled by government (Fisher 1999). Devolution is under the consideration many countries worldwide which are trying to transfer property rights as well as responsibilities from the central government to local people (White and Martin 2002, Edmunds and Wollenberg 2003) aiming at forest conservation (Balooni and Inou 2007) and livelihood improvement (Castella et al. 2006). The actual implementation of devolution is different from place to place due to many different factors and a benefit derived from forest devolution is significantly different (Shackleton and Campbell 2001, Edmunds and Wollenberg 2001, Edmunds et al. 2003). However, there are limited gains from the forest devolution (Balooni and Inou 2007) while the drawback is still prominent: the poor is usually neglected leading to the loss of their livelihood (Edmunds and Wollenberg 2003) while the wealthier groups got the benefit at the expense of the poor (Kumar 2002); Nurse and Malla (2005) also questioned the contribution of forest devolution to rural development because these process in South and Southeast Asia are bounded to secondary and degraded forests (Balooni and Inou 2007).

Community forestry has been considered as a new approach for natural resource conservation and livelihood improvement in Vietnam since forest resource were not sustainably managed by the State forest agencies (De Koninck 1999) while the best remaining forest resources remain under the control of State Forest Enterprises (Sunderlin 2006). In addition to the successful pilots undertaken by the I/NGOs and government agencies at different levels, community forestry has been attached to the FLA through the Land Law 2003 and Forest Protection Law 2004 and these Laws recognized the efforts of those pilots as well as established the legal basis for community forestry in Vietnam.

There have been several studies conducted related to forest and FLA in Vietnam ranging from incentives of the FLA process where they go in deep analyzing the incentives of related stakeholders in FLA process (Ngo and Webb 2008); Studies, for example have reported that in Vietnam, legal rights did not translate into analogous changes in actual rights and practices (Tran and Sikor 2006, Sikor and Nguyen 2007). Changes in land use, for example not only demoted transfer of responsibility to an individual but also gave farmers incentives to make rational use of the land and to protect the resource because once they get the benefits by paying the costs associated with the degradation of the resource (Castella et al. 2006, Tran and Sikor 2006). On the contrary, forestland allocation policy played a major role in land use changes not because it provided the right incentives for farmers to reforest; rather, it was because the forestland allocation disrupted local institutions and collective land use systems (Clement and Amezaga 2009). Moreover, forest re-growth in Vietnam was not due to a single process or policy but to a combination of economic and political responses to forest and land scarcity, economic growth, and market integration at the scale of the country while destruction of old-growth forest continues (Meyfroidt and Lambin 2008). The total forest area remained stable but there were major transition from forest and non-forest categories (Thiha et al. 2007).

Nguyen and Noriko (2006) found really high dependency on forest resources in one community in Nghe An province after forest allocation, the poor households have more than $65 \%$ of their income from forest while the richer have $40 \%$ and it even came up to $75 \%$ for the poorest households (Nguyen and Noriko 2006). There were successful cases when the forest allocation creates greater benefits for forest recipients as well as the associated livelihood diversifications from the government agencies for the communities (Le et al. 
1996; Sikor 2001; Bao 2003; Do et al. 2007). However, there are cases where local people livelihoods was not that improved and the benefit from forestry is less since forest allocation policy do not allow people practice the slash-and-burn cultivation and raise livestock in allocated forest area (Castella et al. 2002, p. 197). The reduction of swidden cultivation overweights the slow increase of paddy production thus reducing the labour productivity (Jakobsen et al. 2007).

Before we go into details of finding, we briefly describe study area and method of information collection and data analysis techniques.

\section{STUDY AREA}

This study was undertaken in Nam Dong district of Thua Thien Hue province, central Vietnam. The total area of Nam Dong is $650.5 \mathrm{~km}^{2}$. Sixty-four percent of the area (416 $\mathrm{km}^{2}$ ) is covered by forest, of which the majority $\left(399.6 \mathrm{~km}^{2}\right)$ is considered as natural forest. Approximately 3,219 ha (5.31\%) of Nam Dong is under permanent, registered agricultural use. Swidden agriculture was historically an important land management system that was practiced along the margins of natural forest and permanent agricultural land, but is now declining in Nam Dong since the government banned swidden agriculture in 1997. The government of Vietnam, through programme 327, initiated an extensive reforestation programme, and in Nam Dong it resulted in extensive establishment of exotic species (Acacia spp., Eucalyptus, Cinnamomum spp., and Hevea brasiliensis) on former swidden and degraded forest lands. Moreover, many former swidden fields have been converted into permanent agriculture. In addition to the effect of the programme 327, "the distribution of forestry land to households, new forest management practices, and food crop intensification were combined in "push and pull" effects to decrease the footprint of agriculture on hillsides (Meyfroidt and Lambin 2008) and forests expanded, mainly due to the liberalization of agricultural output markets and availability of new technology (Sikor 2001).

All forests and forest land (land designated for forestry purposes) are claimed by the state. Oversight and management of forests is the responsibility of the Ministry of Agriculture and Rural Development (MARD) and Ministry of Resources and Environment (MoRE). These two ministries have provincial offices which are Department of Agriculture and Rural Development (DARD) and Department of Resources and Environment (DoRE). The two departments are in charge of the protection, management as well as the allocation of forest land and forests to households and communities (DoRE is in charge of land planning and administration). Thus, there are two agencies responsible for the management of forests in Hue Province. Under DARD, there are Forest Protection Division and Forest Development Division both at the provincial and district levels. They have specific tasks related to the protection and development of forest resources. The main owners of forest and forest land are State Forest Enterprises (SFEs), hence they were really one important actor in forest allocation (prior to 2005). However, due to the weak and inefficient management of the resources, they are converted into Watershed Management Boards and Forestry companies (2005-2007) and large path of forest land under their management were taken back for allocation to local people.

The specific study sites for our research were three communes of Nam Dong district, Hue province (Figure 1). Huong Son is in the southeast region of the district about $8 \mathrm{~km}$ from the district center of Khe Tre. Thuong Quang lies in the southwest region of the district, approximately $17 \mathrm{~km}$ West from Khe Tre and Thuong Long is about $14 \mathrm{~km}$ 
Southwest away from the district center. All communes are accessible by an asphalt road, however historically Thuong Quang and Thuong Long were fairly remote set of villages until 1996. Huong Son consists of 7 Katu villages, Thuong Long has 8 Katu villages and Thuong Quang has 4 Katu and 3 Kinh villages. Forest allocation process initiated in the three communes during 2004 even thought the red book certificate were only released in the late 2006.

Katu people are big group of minority peoples in Thua Thien Hue province and they are the major ethnic group in Nam Dong district: 10292 over the total population of 23875 people in 2008 (Nam Dong statistical book 2008). As many other ethnic groups in Vietnam, they are famous for the rotational swidden cultivation practices and usually lived in the upstream area and their life was heavily dependent on forest resources. Since the sedentarization program (1968) and the ban on swidden cultivation (1997), they were settled down and live permanently in the arranged areas. They learnt to cultivate paddy field and the gardening changing from gatherers and hunting to cultivating and creating conditions for major crops (sustainable and intensive farming). Most of the Katu villages live in and around forests and they still harvest forest products for their daily life even thought before the FLA, forest resources belong to the state. On average, Katu people are poor and Nam Dong is one of the poorest districts of the country (Wetterwald et al 2004)

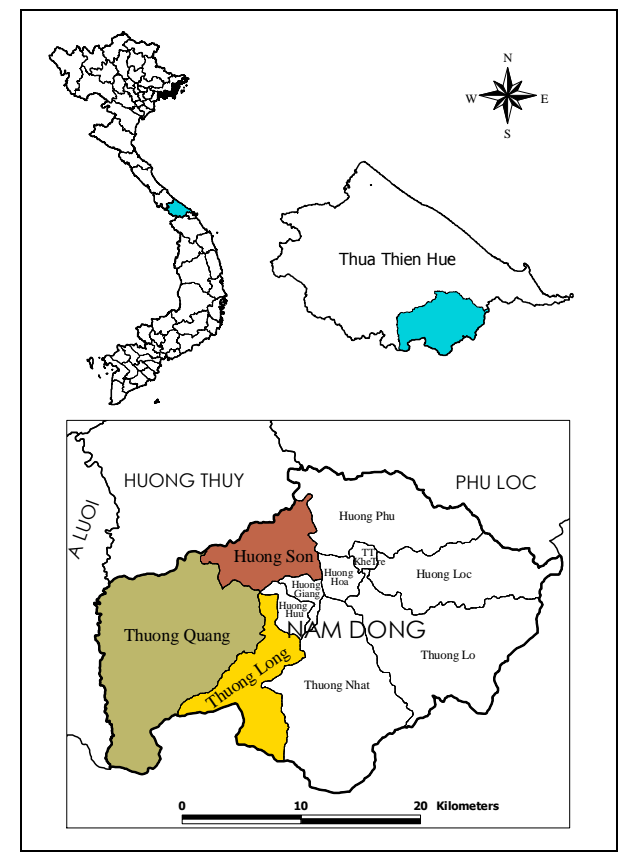

FIGURE 1 Study communes in Nam Dong district, Thua Thien Hue province, Vietnam

Economic indicators suggest that Nam Dong has an average income much lower than the national average. The rural populations of Nam Dong, particularly the Katu households, significantly depend on the forest for their subsistence livelihoods (Wetterwald et al. 2004, Tran 2004) because there is a shortage of flat areas for paddy cultivation and low livelihoods diversification in the area. 


\section{METHODS}

The three communes were selected for research because: (1) they all contain a high percentage of Katu households, all of which have a high dependency on forest for their livelihoods;(2) These communes still possess a high percentage of natural forest cover; and (3) households in the villages have good access both to forest and to markets.

Several preliminary reconnaissance visits were taken to the three study communes to hold informal interviews with key informants and establish a sampling design. Interviews were held with commune leaders and officers, village headmen, and key Katu village elders. The preliminary discussions about property rights, institutions, historical and current forest use and forest dependency revealed that there was a high degree of similarity across Katu villages within a commune and across the three study communes. Based on the preliminary survey, we concluded that one village survey in each commune would be sufficiently representative of Katu villages in Nam Dong. Within each commune, one Katu village, which has allocated forest, was randomly chosen for household surveys. Thus, in this paper we aggregate the results from all three villages to make it representation of Katu people.

From the list of households in the village, we randomly chose the households for questionnaire interview. A total of 96 households were surveyed in this manner out of the total 148 households in the three villages. Semi-structured interviews to investigate historical and current patterns of Katu forest use were conducted with a total of 20 key informants. Key informants were village headmen, village elders, commune leaders, and representatives of the DARD, DoRE, FPD. Finally, a group discussion was held in each village at the end of the field work to discuss the information that had been collected and to build consensus on its reliability. Final revisions were made to ensure that it represented the overall trends seen in Katu villages over the past several years.

Major indicators collected through data collection process:

- Legal rights originated from the current legal documents and regulation of local authorities at province, district and commune level.

- Information on defined rights by group members collected during key information interview and group discussion regarding who are allowed to do what.

- Data are collected through household questionnaire on forest use and forest product extraction, other livelihood activities, changes in forest management and protection before and after FLA.

The qualitative analysis was used for analyzing the legal rights associated with the process, de facto rights generated and practiced by local people. The quantitative analysis involved the SPSS v.13 software. A list of forest use and local livelihoods' variables (Table 4) were developed and analyzed with Pair sample T-test to see the changes in forest use and forest dependency, changes in their livelihoods of local people. 


\section{RESULTS}

\section{FLA process:}

In order to implement the land allocation programme to the communities level, the district authorities based on the district forest management strategy, the available forest and forest land fund, the actual need from local residents (forest for management, protection and barren land for re-forestation), the distribution of the population. Functional agencies, DARD, DoRE come to meet with communes and villages to discuss with local people about the strategy, possibility of forest allocation, listening to their wishes, desires, how they want to manage the forest resources. They work together to form a working group including members of DARD, DoRe, commune officers, villagers. This group would delineate the boundary among communes and villages. They prepare the map, do the forest inventory for the stock evaluation later on. They work with all member of the community to set up the management plan (yearly and five year plan) in management, protection, utilization and after that submit all for the approval from district People's Committee. The benefit sharing mechanism in the plan is based on the Decision 178/2001/QD-TTg of the government. The Chairman of the district People's Committee has the right to approve the allocation plan and release the Land use certificate (Red book) for the recipient communities

In Katu village, due to the traditional cohesion of the community, all forest resources are allocated to the whole community (as the wish of local people). Based on the geographic condition of the forest resources and the traditional possess over forest resources, the villages are chosen for forest allocation. This means within one commune, there are only few villages allocated (it is actually still in the form of experimental forest allocation). This has created two groups: forest recipients and non-recipients at the commune scale. The relationship between villages, therefore have changed accordingly.

\section{Change in the rights and property rights over forest resources}

Since the FLA, there were changes in the rights and property rights of local people on forest resources. Before forest allocation, all forest resources belonged to the State forest enterprises (SFE). Thus, villagers did not have any legal rights toward these forest resources except for the access right. Even for the protection contract (the common form of hiring labour from SFE), local people only played the role of patrolling and protecting forest resources, and in this way, they could be considered as protectors of SFE's forest. However, local people still practice their harvesting of NTFPs in protection and production forest and the stage agencies implicitly let local people to practice their withdrawal right.

TABLE 2 Changes in De jure rights and Property rights in Katu Villages under the FLA

\begin{tabular}{|l|c|c|c|c|}
\hline \multirow{2}{*}{ Rights } & \multicolumn{2}{|c|}{ Before the FLA } & \multicolumn{2}{c|}{ After the FLA } \\
\cline { 2 - 5 } & $\begin{array}{c}\text { Allocated } \\
\text { Village }\end{array}$ & $\begin{array}{c}\text { Neighbor } \\
\text { villages }\end{array}$ & $\begin{array}{c}\text { Allocated } \\
\text { Village }\end{array}$ & $\begin{array}{c}\text { Neighbor } \\
\text { villages }\end{array}$ \\
\hline Access & Yes & Yes & Yes & Yes \\
\hline Withdrawal & No & No & Yes & No \\
\hline Management & No & No & Yes & No \\
\hline Exclusion & No & No & Yes & No \\
\hline Alienation & No & No & Yes, but & No \\
\hline
\end{tabular}


\begin{tabular}{|l|l|l|l}
\hline & & & restricted
\end{tabular}

Under the forest allocation process, the rights are transferred from state to forest recipients and this has changed the relationship between villages. Forest recipients received forest, land and land use certificate (LUC) or red book for the period of 50 years which can be renewable as their wishes and if they manage well their forest. As stated by the Land law 2003 and Forest Protection and Development Law 2004, forest recipients have the basic rights and responsibilities in forest management and benefit sharing mechanism which are regulated by the Decision 178/2001/QD-TTg in particular. However, communities are not allowed to transfer their rights over forest resources to others. The only possibility is that they can mortgage, provide guarantee or contribute capital with added value of forest use rights. This is the reason why we put "Yes, but restricted" for the alienation right of the allocated village (table 2). Meanwhile the rights of non-recipients (neighbor villages) are unchanged.

There are great changes in the management activities of recipient villages. With the support of local authorities or national, international NGOs for the study villages such as The Green Corridor project, The Tropenbos International, the SNV (Netherland Development Organization), ETSP/Helvetas (Swiss Association for International Cooperation. ETSP Extension and Training Support Project for Forestry and Agriculture in the Uplands), CORENARM (a local NGO - Consultative and Research Center on Natural Resource Management), recipient villages did the forest inventories to see what exactly they do have in the community forests, and from then make the detailed plan for forest management, building up the nursery gardens for the replanting and enrichment of the forest, rehabilitation, formed the patrol groups in each village and do the patrolling throughout their forest regularly (two times/month). During the patrol, they protect the forest by excluding the violation of encroachers in case of timber logging or animal hunting, performing the management activities such as clearing the climbers, fire prevention, observing changes in their forest in order to have proper management activities.

Under the FLA process, both the de facto and de jure rights of local people have changed accordingly, which are presented in the table 3.

TABLE 3 Changes in De jure and De facto rights in Katu Villages under the FLA

\begin{tabular}{|l|c|c|c|c|}
\hline \multirow{2}{*}{ Rights } & \multicolumn{2}{|c|}{ De jure rights } & \multicolumn{2}{c|}{ De facto rights } \\
\cline { 2 - 5 } & $\begin{array}{c}\text { Allocated } \\
\text { Village }\end{array}$ & $\begin{array}{c}\text { neighbor } \\
\text { villages }\end{array}$ & $\begin{array}{c}\text { Allocated } \\
\text { Village }\end{array}$ & $\begin{array}{c}\text { neighbor } \\
\text { villages }\end{array}$ \\
\hline Access & Yes & Yes & Yes & Yes \\
\hline Withdrawal & Yes & No & Yes & Yes, but limited \\
\hline Management & Yes & No & Yes & No \\
\hline Exclusion & Yes & No & Yes but loose & No \\
\hline Alienation & $\begin{array}{c}\text { Yes, but } \\
\text { restricted }\end{array}$ & No & $\begin{array}{c}\text { Yes, but } \\
\text { restricted }\end{array}$ & No \\
\hline
\end{tabular}

With the imposition from the forest allocation process, forest recipients have all the rights over their forest resources both on the de jure and de facto aspects. For withdraw right, recipient villages have all the rights to the NTFPs products except for the wildlife list regulated by the Decree 32/2006/ND-CP of the government. For timber, local people would 
benefit from the growth and amount stipulated in Decision 178/2001/QD-TTg by the Prime Minister. However, this needs the participation of Forest protection department and district functional agencies to be able to implement in the field and since they day of first implementing the plot of CFM, only one villages in Daklak province and one village in Thua Thien Hue province has the experiment harvesting of timber resource (Oberndorf et al. 2006). For the exclusion right, recipient village have the full exclusion rights with outsiders encroaching their forest. However, they only perform it to a certain level. They still allow outsiders to come and harvest NTFPs in their forest. Being asked about the reason why recipient villages are "loose" about their exclusion right, local people mentioned that: (1) The forest area is adjacent to each other and there is no clear boundary or fence for the private protection; (2) Local people used to have "open access" to the state forest and people are used to harvest NTFPs products anywhere they want; (3) People in the village, commune all know each other and they feel difficult to stop their neighbours from harvesting the NTFPs product. In addition, previously these forest area were also used to be the harvesting place of other villages so to present time, they still carry out their traditional practices; and (4) the amount of products harvest is really small due to the depletion of resources thus they do not care if it is harvested by outsiders. In the year 2009, the three villages found 4 violations related to timber logging in their forests. They managed themselves 2 cases and informed the commune and Forest protection unit for support in dealing with the other 2 cases of armed encroachers. These are the new management activities introduced with the allocation of forest to local communities.

Meanwhile, with the non-recipient villages, they do not have the de jure rights except for the access right over the forest allocated to recipient villages. However, on the de facto aspect, non-recipient villages still can enjoy the benefit of NTFPs on the allocated forest thank to the loose exclusion of recipient villages and they do not have this right with timber resource. Being limited by the types of products and dependency on the will of recipient villages, we call the de facto withdrawal right of non-recipient villages as "limited" withdrawal right.

\section{Changes in forest use and forest dependency:}

Katu people has long dependent tradition on forest resources. They live in the upstream area and almost all of their daily food and foodstuff come from forest. In the past, they are the self-existent communities who live separately in the remote area with very low exchange with outsiders. Until 2004, Katu people in Nam Dong had very high forest dependency for subsistence and additional income (Wetterwald et al 2004) and the majority of Katu households have $11-50 \%$ of their total income from forest (Tran 2004).A list of several forest use and local livelihood variables and pairs for the Pair sample T-test are presented in table 4.

Through table 4, we can see that most of the forest use and local livelihood variables before and after allocation are significantly different and only one insignificant difference is in the use of medicinal plants. Income from forest, grazing and agriculture are significantly different from the two time period while income from outside is not significantly different. Total income is slightly different at $\mathrm{p}$ value $<.05$ at the downward trend which mean total income of local people at the present is even lower than before forest allocation. 


\begin{tabular}{|c|c|c|c|c|c|}
\hline No & Variable names & Unit \& notes on variables & Mean & $\mathbf{t}$ & $\begin{array}{c}\text { Sig. } \\
\text { (2-tailed) }\end{array}$ \\
\hline Pair 1 & No.entry1 - No.entry2 & Times (times of forest entries/month) & 0.56 & 3.76 & $0.0003 * * *$ \\
\hline Pair 2 & daymonth1 - daymonth2 & $\begin{array}{l}\text { Days (No. of days people spend in } \\
\text { forest } / \text { month) }\end{array}$ & 3.99 & 8.71 & $0.0000 * * *$ \\
\hline Pair 3 & prodcsale 1 - prodcsale 2 & $\%$ (percent of forest product for sale) & 39.64 & 9.04 & $0.0000 * * *$ \\
\hline Pair 4 & Noofspecies1 - Noofspecies2 & $\begin{array}{l}\text { Species (No. of species people usually } \\
\text { harvest) }\end{array}$ & 2.51 & 8.80 & $0.0000 * * *$ \\
\hline Pair 5 & Fuel1 - Fuel2 & $\begin{array}{l}\text { Bunches (No. of fuel bunches people } \\
\text { take/month) }\end{array}$ & 0.96 & 5.86 & $0.0000 * * *$ \\
\hline Pair 6 & Rattan1 - Rattan2 & $\begin{array}{l}\text { Canes (amount of rattan } \\
\text { harvested/month) }\end{array}$ & 69.90 & 6.76 & $0.0000 * * *$ \\
\hline Pair 7 & Honey1 - Honey2 & $\begin{array}{l}\text { Bottle (No. honey bottles people } \\
\text { harvest/year) }\end{array}$ & 1.94 & 5.08 & $0.0000 * * *$ \\
\hline Pair 8 & hatleave1 - hatleave2 & $\begin{array}{l}\text { Leaves (No. of Rhapis laosensis leaves } \\
\text { people harvest/month) }\end{array}$ & 170.52 & 4.30 & $0.0000 * * *$ \\
\hline Pair 9 & broom 1 - broom 2 & $\begin{array}{l}\text { Kgs (Amount of the Thysanolaena } \\
\text { maxima harvest/month) }\end{array}$ & 0.21 & 0.07 & 0.9421 \\
\hline Pair 10 & Mushroom1 - Mushroom2 & $\begin{array}{l}\text { Kgs (Amount of mushroom people } \\
\text { harvest/year) }\end{array}$ & 1.15 & 6.02 & $0.0000 * * *$ \\
\hline Pair 11 & Fruit1 - fruit2 & $\begin{array}{l}\text { Kgs (Amount of fruits people } \\
\text { harvest/year) }\end{array}$ & 2.05 & 2.70 & $0.0082 * *$ \\
\hline Pair 12 & Medicinal1 - Medicinal2 & $\begin{array}{l}\text { 1: the household do collect } \\
0: \text { the household do not collect }\end{array}$ & 0.07 & 1.72 & 0.0896 \\
\hline Pair 13 & $\begin{array}{l}\text { Forestincome1 - } \\
\text { Forestincome2 }\end{array}$ & VND (total income from forest/year) & 1148337.50 & 7.22 & $0.0000 * * *$ \\
\hline Pair 14 & Agriincome1 - Agriincome2 & $\begin{array}{l}\text { VND (total income from } \\
\text { agriculture/year) }\end{array}$ & (1 335833.33$)$ & $(8.53)$ & $0.0000 * * *$ \\
\hline Pair 15 & Grazincome1 - Grazincome2 & $\begin{array}{l}\text { VND (total income from animal } \\
\text { husbandry/year) }\end{array}$ & $(723673.61)$ & $(6.04)$ & $0.0000 * * *$ \\
\hline Pair 16 & Osideincome1 - Osideincome2 & $\begin{array}{l}\text { VND (total income from } \\
\text { outsides/year) }\end{array}$ & 238058.33 & 0.96 & 0.3381 \\
\hline Pair 17 & Totalincome1 - Totalincome 2 & $\begin{array}{l}\text { VND (total income from all } \\
\text { sources/year) }\end{array}$ & $(673111.11)$ & $(2.06)$ & $0.0421 *$ \\
\hline Pair 18 & Foresttotal1 - foresttotal2 & $\begin{array}{l}\% \text { (ratio of income from forest/total } \\
\text { income) }\end{array}$ & 11.44 & 7.89 & $0.0000 * * *$ \\
\hline Pair 19 & Agritotal1 - Agritotal2 & $\begin{array}{l}\% \text { (ratio of income from agri./total } \\
\text { income) }\end{array}$ & $(7.53)$ & $(6.22)$ & $0.0000 * * *$ \\
\hline Pair 20 & Grazttotal1 - Grazttotal2 & $\begin{array}{l}\% \text { (ratio of income from animal } \\
\text { husbandry/total income) }\end{array}$ & $(5.69)$ & $(5.90)$ & $0.0000 * * *$ \\
\hline Pair 21 & Outtotal1 - Outtotal2 & $\begin{array}{l}\% \text { (ratio of income from outside/total } \\
\text { income) }\end{array}$ & 1.78 & 0.95 & 0.3447 \\
\hline Pair 22 & Inperyear1 - Inperyear2 & $\begin{array}{l}\text { VND (income/person } \\
\text { /year) }\end{array}$ & $(196334.03)$ & $(2.81)$ & $0.0060 * *$ \\
\hline Pair 23 & Inpermonth1 - Inpermonth2 & VND (income/person /month) & (16 361.17) & $(2.81)$ & $0.0060 * *$ \\
\hline
\end{tabular}

Note:

- $\quad * \mathrm{p}<.05, * * \mathrm{p}<.01, * * * \mathrm{p}<.001$

- VND: Vietnamese Dong

- 1 USD = approximately VND 16000 during study period of 2009.

With regard to the number of forest entries and days spent in forest, in comparison to the past, local people have less number of forest entries and days spent in the forest and the differences in the two times period is significant. Similarly, the number of species harvested and ratio of product for sale, it is not only limited to the time spent on forestry activities but actually local people have also reduced the actual use of forest resources. These patterns are explained by the number of species they harvest (from 5.81 down to 3.30 species) and the ratio of product sold against harvested which has come down from $69.9 \%$ to $30.26 \%$. Local people confirmed that the amount of product harvested is too small so that people mainly harvest for subsistence instead of selling products. 
Fuel-wood collection is an important and integral part of local forest usage. The collections of fuel-woods, even though a hard work, are mainly done by women in the study villages. Local people usually harvest the dried branches or stems of tree in the forest and carry home on a big local back pack (equivalent to one bunch with the weight of around 30$35 \mathrm{~kg} / \mathrm{bunch}$ ) which in this study is used as a unit of the fuel-wood usage. Previously people used higher amount of fuel wood (3.20 bunches/month) and recently they only consume 2.24 bunches. This is because local people have the fuel-wood from their own home garden and plantation (thinning of the branches of their own plantation). Some households have started using gas.

Of the forest products (such as Rattan, Honey, the broom making plant (Thysanolaena maxima), hat making plant (leaves of Rhapis laosensis), Mushroom, Fruit), all have the same pattern of reduction trend except for the case of the broom making plant. This was confirmed by local people that all these products are being rare compared to the past and it takes much time for local people to find and harvest these products. However, the broom making plant is a herbaceous species that grow widely in the secondary, degraded or open canopy forest, thus making its availability in abundance. This explains that there is no difference in the harvesting intensity of only this product by the local people.

Due to the changes in forest use pattern, the incomes from forest have changed accordingly. Thus, the contributions of income from forest to the total income of local people have dramatically reduced.

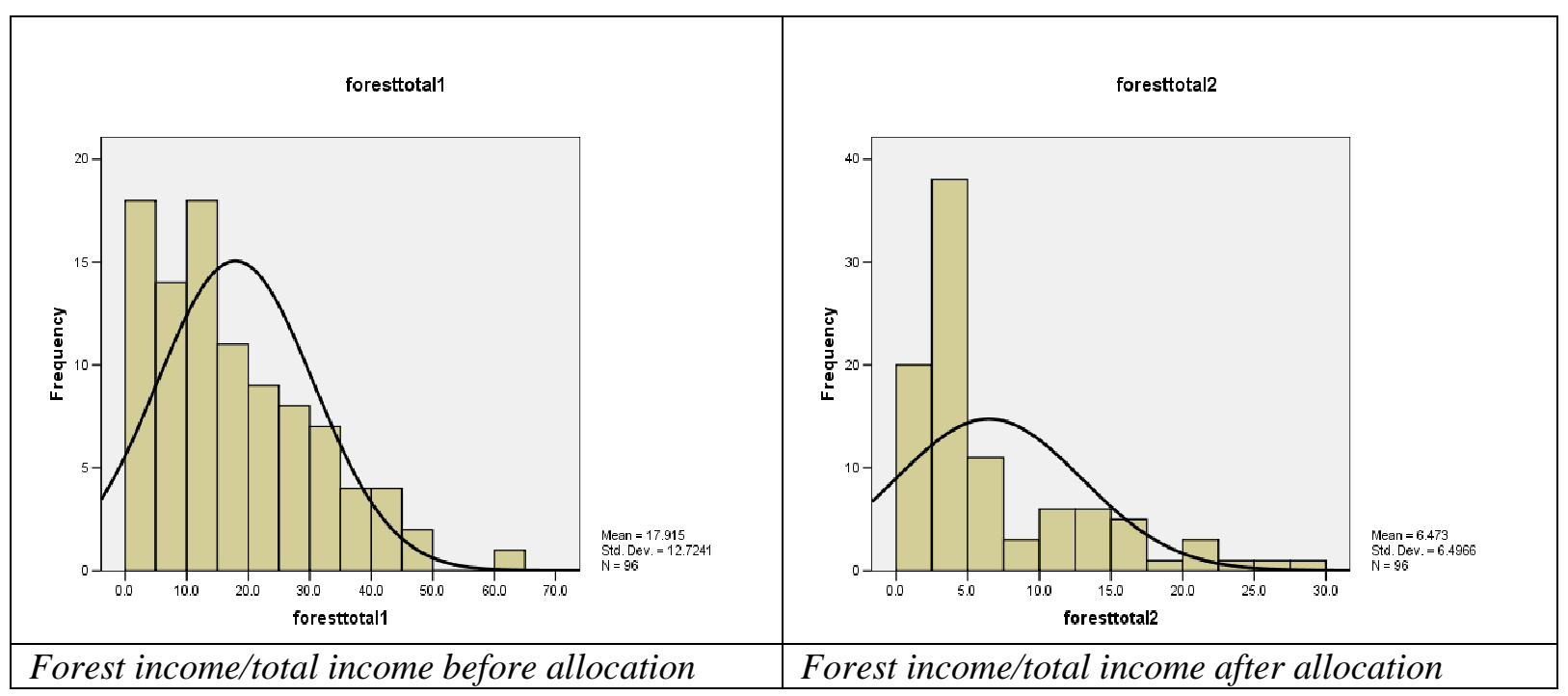

FIGURE 2 Change in forest income and forest dependency of local people before and after forest allocation

Along with the downward change in income from forest, other sources of income of local people have also changed overtime. The income structure of local people after forest allocation in the study area is presented in table 5. This shows the only internal changes in the income structure of local people with the diversification of agriculture and animal grazing options. 
TABLE 5 Changes in forest dependency index and income structure

\begin{tabular}{|l|l|c|c|c|}
\hline \multirow{2}{*}{ Means of income ratios } & \multirow{2}{*}{ Unit } & \multicolumn{2}{|c|}{ Changes after allocation } & \multirow{2}{*}{ Notes } \\
\cline { 3 - 4 } & & Before & After & \\
\hline Forest income/total income & $\%$ & 18.17 & 7.06 & IFD \\
\hline Agriculture income/total income & $\%$ & 54.86 & 56.79 & \\
\hline Animal husbandry income/total income & $\%$ & 15.23 & 24.54 & \\
\hline Non-farm income/total income & $\%$ & 11.74 & 11.61 & \\
\hline
\end{tabular}

Note: IFD: Index of forest dependency: The ratio of income from forest and total income of the family. This shows to what level a household is dependent on forest resources in the study area.

There are big decline on forest dependency of local people before forest allocation compared to the present time, which has come down from $18.17 \%$ to $7.06 \%$. This indicates the shift of natural resource dependent life of local people toward a production-based system in agriculture and animal husbandry activities.

This downward trend of forest dependency of local people in study area questions often taken for granted panacea that allocating forest to the community users will increase the destruction of forest by over harvest. Although being recipients of forest resources means having higher individual and community rights toward the forest, forest land and other products on their forest land. Local people in contrast are less dependent on forest resources for their livelihood. The reason for forest product reduction were that the forest products are becoming more and more scare due to over extraction and poor status of allocated forest. Group discussion also revealed that forestry activities imply low income in the short time with labour intensive requirement as well as the associated risks due to complex topographic conditions and unexpected threats and the local people tend to change to other livelihood options due to alternative choices available for people in the livelihood diversification options and changes in local people's income structure due to opportunities for improved methods of agriculture production and animal husbandry activities. The allocated forests, at present, are perceived by local people as the long term low cost investment for future family security.

\section{DISCUSSION}

Local people have actively participated in the FLA process and they played the main role in most of the related activities, from discussing, decision making, implementing, monitoring and evaluation. This process not only require te participation of local people but also demand the support, participation of local authorities, functional agencies to help implement all related activities in the field.

Before forest land allocation, local people have non-written access and withdrawal rights over forest resources with de facto rights of harvesting NTFP products in both the protection and production forests. With forest allocation programme, recipient villages experienced great change in their property rights over forest resources. From only having the access rights to having almost full bundles of rights toward forest resources was a great achievement of the FLA programme. From the point of view on the resource management theory, this would largely contribute to the protection and management incentives for local people and alter the governance structure and the rights of users over forest resources 
(Meinzen-Dick and Knox 2001). With these changes, the de jure right of the forest recipients and non-recipient are concretely different. It allow forest recipients to have almost full rights in general while the rights of non-recipients stay the same with the access rights over the allocated forest resources.

On the de facto aspect, rights of non-recipient villages are different from the de jure rights. People in adjacent villages or even different communes would still have the rights of withdrawal "legal" forest products over allocated forest (legal NTFPs and the agreement of the allocated village) and non-written access and withdrawal rights over state forest resources. This agreement for the legal harvesting of outsiders occurs in all the three study villages show the close relationship among local villages as well as the loose management and protection of their natural capital. Moreover, most of the allocated forests are poor and degraded, thus the quantity and quality of forest products are low and local people do not have the incentives to protect those resources. Actually, for legal NTFP products to this moment in the study area, both recipients and non-recipients practice the same withdrawal rights for both allocated forest and state's forest. With recipient villages, they at the same time have the full bundles of rights over their allocated forest and, like non-recipients, the non-written access and withdrawal rights over state forest. This, in principal, will allow forest recipients to have greater legal share of benefit from forest compared to non-recipients in the same commune. However, these changes, up to the moment, have not brought about much of the short-term benefit and contributed to the livelihood of local Katu people.

To the present, forest recipients have only practiced access, withdrawal, management and exclusion rights over their forest resources. As specified in the Law on Forest Protection and Development (2004), allocated communities are not allowed to "divide forests among their members; not to convert, transfer, donate, lease, mortgage, provide guarantee or contribute business capital with, the value of the use rights over the assigned forests". They are only allowed to "mortgage, provide guarantee or contribute capital with, only the added value of forest use rights, that is brought about by forest owners' investments as compared to the forest use right value determined at the time of being leased forests according to law provisions". This would make it complicated for local communities in obtaining their full rights over their allocated resources.

Beside the exclusion and alienation rights, the other de facto difference between recipients and non-recipient, the timber incentives, would take too long for forest recipients to be able to benefit from this source due to the low quality of allocated forest. There are several reasons for the degraded conditions of the allocated forest (Sunderlin 2006) or in another word, state forest enterprises manage most of the valuable natural forests (Balooni and Inoue 2007) or worse, when the state forest enterprise delay forest allocation and maximize timber extraction before allocation (Dzung and Webb 2007). Thus, in the short and medium term, there are not much difference between the forest recipients and non-recipients in term of actual benefit from forest resources. This, to some extent affect to the incentive and participation of local people on forest protection and management activities.

In contrast to the higher level of property rights over forest resources, the forest use and forest dependency of forest allocated community reduces compared to the past. This is in 
contradiction to other study (Jakobsen et al. 2007) where he found the really high level of forest dependency in one community in Nghe An province after forest allocation.

In addition to the reduction of forest use, the increase of incomes from agriculture production and animal husbandry are also other reasons that make the contribution of forest resources to income of local people smaller, or in another word, Katu people are less dependent on forest resources. People have different choices due to higher livelihood diversification options so that they can earn their living though agriculture extensive farming: increasing the area (converting from swidden field) and yield of cash crop, increasing the yield of paddy field. Local people also increase the productivity of their home garden thanks to the cultivation techniques; re-design their mixed, low productive gardens with high economic value species. In the animal husbandry, there are significant increase in the income from livestock grazing and pig rising. There are almost no changes in the non-farm income of local people including the sub-categories such as income from outside, income from small business and income from pension/wage. These increases in agriculture and animal grazing are thanks to the supports both from the government and I/NGOs programmes/projects on agriculture diversification, improving the mixed and ineffective home garden, the VAC programme to promote the integration model of home garden, fishery and animal (V stands for garden, A for pond and $\mathrm{C}$ for caged animal), the overall management of Agriculture Extension who transfer the technique and look after the diseases for the castle and animal as well as the self exposure to the market economy where local people start participating in the market-oriented production.

It is really a shock to see that there were no significant changes in the total income of local people which means local people did not get any increase in their income within the last five years after forest allocation. The income structure shifts the dependence from forest to other sources or income from forest is compensated by the income increase from agriculture and livestock production. This really means local people lost the income from forest. This shows a grey picture of the Katu people's standard of living in specific and Nam Dong people in general. Forest did not support local people livelihood as the wishes of local people when receiving forest allocation and the local authorities' objective of FLA process which is to improve living standards of mountain populations (Castella et al, 2006). In fact, the contribution of allocated forest to local livelihood has not been achieved and the valuable traditional knowledge of local people has not been properly utilized as it should be. However, group discussion reavealed that, the low income from forest resource may also be because of the fact that the forest plantations of local people on allocated barren forest land have not reach the age of harvesting thus the income from forest is still low at the time of data collection period. They would be ready for harvesting in the next 2-3 years.

\section{CONCLUSION}

In general, there are positive changes in the participation of local people in forest conservation and management; changes in the property right and rights; and changes in forest use and forest dependency of local people over forest resources as a result of forest allocation programmes in the three study villages. The changes include the de jure and de facto rights to both forest recipient villages and non-recipient villages. Forest recipient villages have the full bundles of rights both from de jure and de facto rights confirming their absolute ownership over the allocated forest resources. This, on theory, would ensure incentives for local people 
to participate and contribute toward protection and management of allocated forest. Recipient villages almost have full de jure rights toward allocated resources except for the "restricted" right on alienation. They cannot transfer the rights of community to others. Katu people do not practice strong de facto rights toward the harvesting of NTFPs in their community forests. The non-recipient villages, to the present, enjoy the "limited" benefit from the defined and practiced de facto rights of recipient villages. This implies the "loose" management and protection of allocated forest resources by forest recipients.

From the difference in the de jure and de facto rights over forest resource of Katu people, we can conclude that: (1) to some extent, it shows the influence of long tradition on forest management of Katu people and the community sense in their daily activities. Community forestry was a tradition in Katu communities because they have been living on forest resources for centuries and the community sense only faded out since the state forest management (1976 - early 1990s); (2) It also shows great impact of state management on daily life of Katu people, people still have the sense that the forest resource is open for access as a common pool resource; and (3) The resources are so poor that it cannot create strong enough incentives for recipient villages to care about protecting them.

Our finding confirm the findings of Tran and Sikor (2006) that the legal rights and actual rights are not necessary translated analogously from laws and regulation to property rights and land use practices, and forest allocation and property rights transfers are only the first steps in sustainable natural resource management.

Surprisingly, forest use and forest dependency of forest recipients reduce significantly compared to the past both in the quality and quantity. It is really in contradiction with the changes in property rights of local people. This, in short, are the waste of resources and the ineffectiveness of natural resource management that should be taken into consideration both at the policy making level and the grass-root community level.

Moreover, with the creation of forest recipients and non-recipients having different property rights over forest resources during the forest land allocation process, we argue that it would create conflicts in the long run as well as constrains in achieving sustainable forest resource management. This should be considered by the government and local authorities for forest development strategies and the implementation of CFM in order to better conservation of forest resources and to improve livelihood of local people.

The result of this study suggests that the government of Vietnam should consider the difference in de jure and de facto rights in the local contexts. These different rights, sometimes, would have great contribution to the improvement or reduction of the conservation of forest resources and livelihood of local people. The customary tradition of local people should be respected and considered before and during the implementation of CFM. In addition, the knowledge of local on forest usage and management should be utilized so that the desired outcomes of forest allocation would be achieved. Moreover, there is a need to have supporting policies and post-allocation programmes that create incentives for local people to protect and invest in the allocated forest and help forest recipients enjoy more benefit from their protection and management of allocated forest thought sivilculture 
techniques, investment and loans for long term production models and additional values through international and national promising programmes such as payment for environmental services, REDD, upland watershed protection reward. These supporting policies would create long term incentives for local people to better protect and manage their forest resources. This is also in agreement with Nguyen (2006) that to make people benefit from forest devolution, the state policy should not only focus on how people get rights to devolved forest but also on how people derive true economic benefits from it. 


\section{REFERENCE}

BALOONI, K., M. INOUE. 2007. Decentralized forest management in south and Southeast Asia. Journal of Forestry 105 (8): 414-420.

BAO, H. (2003) Participatory technology development on natural forests allocated to the M'nong ethnic community. Social forestry support program. Tay Nguyen University, Tay Nguyen

BROMLEY, D.W., 1989b. Property rights and institutional change. Economic Interest and Institutions: The Conceptual Foundations of Public Policy. Basil Blackwell Inc., New York.

BRUCE, J.W. 1998. Review of tenure terminology. Tenure Brief 1,1-8.

CASTELLA, J.C. BOISSAU, S. THANH, N.H. NOVOSAD, P. 2002. Impact of forestland allocation on agriculture and natural resources management in Bac Kan province, Vietnam. In: Castella JC, Quang DD (eds) Doi Moi in the mountains: land use changes and farmers' livelihood strategies in Bac Kan province, Vietnam. Agricultural Publishing House, Hanoi, pp 197-220

CASTELLA, J.C., BOISSAU, S., THANH, N.H., NOVOSAD, P. 2006. Impact of forestland allocation on land use in a mountainous province of Vietnam. Land Use Policy 23 (2): 147160.

CLEMENT, F., AMEZAGA, J. M. 2009. Afforestation and forestry land allocation in northern Vietnam: Analyzing the gap between policy intentions and outcomes. Land Use Policy 26 (2): 458-470.

DE KONINCK, R. 1999. Deforestation in Viet Nam. Ottawa, IDRC, 101 p. (ISBN 0- 88936-869-4)

DO, D.S. HOANG, L.S. LE, Q.T.. 2007. Forest governance in Vietnam. In: Decentralization and state-sponsored community forestry in Asia. Institute for Global Environmental Strategies (IGES), pp 139-159

EDMUNDS, D. WOLLENBERG, E. 2001. Historical perspectives on forest policy change in Asia: an introduction. Environmental History 6, 190-212.

EDMUNDS, D. WOLLENBERG, E. 2003. Local Forest Management: The Impacts of Devolution Policies. Earthscan Publication, London.

FISHER, R. 1999. Devolution and Decentralization of Forest Management in Asia and the Pacific, Unasylva, 50(4): 3-5

JAKOBSEN, J. RASMUSSEN K. LEISZ, S. FOLVING, R. NGUYEN, V.Q. 2007. "The effects of land tenure policy on rural livelihoods and food sufficiency in the upland village of Que, North Central Vietnam." Agricultural Systems 94(2): 309-319.

HANN, C.M. 1998. Introduction: the embeddedness of property. In: Hann, C.M. (Ed.), Property Relations: Renewing the Anthropological Tradition. Cambridge University Press, Cambridge, UK, pp. $1-47$.

KUMAR, S. 2002. Does "Participation" in common pool resource management help the poor? A social cost-benefit analysis of joint forest management in Jharkhand, India. World Dev. 30(5):763-782. 
LE, V. L., ZIEGLER, S., GREVER, T. 2002. Utilization of forest products and environmental services in Bach Ma National Park, Vietnam. Hanoi Vietnam: German Development Service

LE, T. C. RAMBO, A.T. FAHRNEY, K. TRAN, D.V. ROMM, J. SY, D.T. 1996. Red Books, Green Hills: The Impact of Economic Reform on Restoration Ecology in the Midlands of Northern Vietnam. CRES, Hanoi University. Southeast Asian Universities/Agroecosystem Network. East-West Center/Program on Environment, University of California, Berkeley

MACPHERSON, C.B. 1978. The meaning of property. In: MacPherson, C.B. (Ed.), Property: Mainstream and Critical Positions. University of Toronto Press, Toronto, pp. $1-13$.

MEINZEN-DICK, R., KNOX, A. 2001. Collective action, property rights, and devolution of natural resource management: a conceptual framework. In: MEINZEN-DICK, R., KNOX, A. AND DI GREGORIO, M., (ed.) Collective Action, Property Rights and Devolution of Natural Resource Management. German Foundation for International Development, International Food Policy Research Institute, and International Centre for Living Aquatic Resource Management, Feldafing, Germany.

MEYFROIDT, P., LAMBIN, E. F. 2008. The causes of the reforestation in Vietnam. Land Use Policy 25 (2): 182-197.

NGUYEN, V. Q. AND NORIKO S. (2008). "Forest Allocation Policy and Level of Forest Dependency of Economic Household Groups: A Case Study in Northern Central Vietnam." Small-Scale Forestry 7(1): 49-66.

NGO, T. D., WEBB, E. L. 2008. Incentives of the forest land allocation process: implications for forest management in Nam Dong district, Central Vietnam. In: WEBB, EDWARD AND GANESH P. SHIVAKOTI. (ed.) Decentralization, Forests and Rural Communities: Policy Outcomes in South and Southeast Asia. Sage Publications-New Delhi/Thousand Oaks/London.

NURSE, M. MALLA, Y. 2005. Advances in community forestry in Asia. Regional Community Forestry Training Center for Asia and the Pacific. Bangkok, Thailand.

OBERNDORF, R. DURST, P. MAHANTY, S. BURSLEM, K. SUZUKI, R. 2006. A Cut for the Poor. Proceedings of the International Conference on Managing Forests for Poverty Reduction: Capturing Opportunities in Forest Harvesting and Wood Processing for the Benefit of the Poor. Ho Chi Minh City, Viet Nam 3-6 October 2006

POFFENBERGER, M., DZUNG, N. H., PHON, N. H., WALPOLE, P., SIKOR, T., CHUNG, V. T., DZUNG, V. V. 1998. Stewards of Vietnam's Upland Forests: A Collaborative Study by the Asia Forest Network and the Forest Inventory and Planning Institute. Research network Report Number 10.

SCHLAGER, E. OSTROM, E. 1992. Property-rights regimes and natural resources: a conceptual analysis. Land Economics 68 (3) (1992), pp. 249-262 (August)

SIKOR, T. 2001. The allocation of forestry land in Vietnam: did it cause the expansion of forests in the northwest? Forest Policy and Economics 2: 1-11 
SIKOR, T., NGUYEN, Q. T., 2007. Why may forest devolution not benefit the Rural poor? Forest Entitlements in Vietnam's Central Highland. World Development 35 (11): 2010-2025.

SHACKLETON, S. CAMPBELL, B. 2001. Devolution in Natural Resource Management: Institutional Arrangements and Power Shifts. A Synthesis of Case Studies from Southern Africa. Center for International Forestry Research, Harrare.

SUNDERLIN, W. D. 2006. Poverty alleviation through community forestry in Cambodia, Laos, and Vietnam: An assessment of the potential. Forest Policy and Economics 8: 386- 396.

TRAN, N. T., 2004. Forest use pattern and forest dependency of Katu communes of Nam Dong district, Hue province, Vietnam. M.Sc. thesis, Asian Institute of Technology, Bangkok.

TRAN, N. T., SIKOR, T. 2006. From legal acts to actual powers: Devolution and property rights in the Central Highlands of Vietnam. Forest Policy and Economics 8 (4): 397-408.

THIHA, WEBB, E. L., HONDA, K. (2007). Biophysical and policy drivers of landscape change in a central Vietnamese district. Environmental Conservation: page 1 of 9 (c) 2007 Foundation for Environmental Conservation

WETTERWALD, O., ZINGERLI, C., SORG, J., (2004). "Non-timber Forest Products in Nam Dong District, Central Vietnam: Ecological and Economic Prospects." Ecological and Economic Prospect 155(2): 45-52.

WHITE, A. MARTIN, A. 2002. Who Owns the World's Forests? Forest Tenure and Public Forests in Transition. Forest Trends and Center for International Environmental Law, Washington, DC. 